\title{
A FIXAÇÃO DE MANDATOS PARA OS MINISTROS DO SUPREMO TRIBUNAL FEDERAL À LUZ DO PRINCÍPIO DEMOCRÁTICO E REPUBLICANO: ANÁLISE DA PROPOSTA DE EMENDA CONSTITUCIONAL N ${ }^{\circ} 35$ DE 2015
}

THEFIXING OFMANDATESFORMINISTERSOFTHESUPREMEFEDERAL COURTINLIGHT OFTHEDEMOCRATICANDREPUBLICANPRINCIPLE:ANALYSISOFTHEPROPOSALOF CONSTITUTIONAL AMENDMENT NO. 35 OF 2015

LAFIJACIÓNDEMANDATOSPARALOSMINISTROSDELSUPREMOTRIBUNALFEDERAL ALALUZDELPRINCIPIODEMOCRÁTICOYREPUBLICANO:ANÁLISISDELAPROPUESTA DE ENMIENDA CONSTITUCIONAL No 35 DE 2015

Licença CC BY:

Artigo distribuído sob os termos Creative Commons, permite uso e distribuição irrestrita em qualquer meio desde que o autor credite a fonte original.

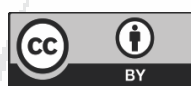

\section{Emerson Affonso da Costa Moura ${ }^{1}$}

RESUMO: A análise da proposta de Emenda Constitucional $n^{\circ} 35$, que altera o artigo 101 da Constituição Federal para alteração do acesso e da permanência dos ministros do Supremo Tribunal Federal, é o tema posto em debate. Analisa em que medida a fixação de mandato para os ministros da corte constitucional se demonstra a concretização do princípio democrático e do princípio republicano. Para tanto, verifica-se o papel assumido pela corte constitucional brasileira, os limites do papel do contramajoritário e o princípio democrático e republicano à luz do acesso e da permanência dos ministros no Supremo Tribunal Federal.

PALAVRAS-CHAVES: Supremo Tribunal Federal; Ministros; PEC 35/2015; Princípio Democrático; Princípio Republicano.

1 Professor Adjunto da Universidade Federal Rural do Rio de Janeiro (UFRRJ) no Estado do Rio de Janeiro, Brasil. Professor Convidado da Pós-Graduação em Direito Administrativo da Escola de Magistratura do Rio de Janeiro (EMERJ). Doutor em Direito pela Universidade do Estado do Rio de Janeiro (UERJ). E-mail: emersonacmoura@ yahoo.com.br 
ABSTRACT: The subject raised for debate is proposal of Constitutional Amendment no. 35, which alters article 101 of the Federal Constitution, changing the access and permanence of the ministers of the Federal Supreme Court. This work examines the extent to which the establishment of a mandate for the ministers of the constitutional court demonstrates the realization of the democratic principle and the republican principle. For this, it investigates the role assumed by the Brazilian constitutional court, the limits of the role of the countermajority, and the democratic and republican principle in light of the access and permanence of the ministers in the Federal Supreme Court.

KEYWORDS: Supreme Federal Court; Ministers; PEC 35/2015; Democratic Principle; Republican Principle.

RESUMEN: El análisis de la propuesta de Enmienda Constitucional $n^{\circ} 35$, que altera el artículo 101 de la Constitución Federal para alteración del acceso y de la permanencia de los ministros del Supremo Tribunal Federal, es el tema puesto en debate. Analiza en qué medida la fijación del mandato para los ministros de la corte constitucional demuestra la implementación del principio democrático y del principio republicano. Para tanto, se verifica el papel desempeñado por la corte constitucional brasileña, los límites del papel del contra mayoritario y el principio democrático y republicano a la luz del acceso y de la permanencia de los ministros en el Supremo Tribunal Federal.

PALABRAS CLAVES: Supremo Tribunal Federal; Ministros; PEC 35/2015; Principio Democrático; Principio Republicano.

\section{INTRODUÇÃO}

A proposta de Emenda Constitucional $n^{\circ} 35$ de 2015 que se encontra em trâmite traz a lume novamente uma proposta de alteração do artigo 101 da Constituição Federal para modificar a forma da escolha, bem como a fixação de um mandato para os ministros do Supremo Tribunal Federal.

Na proposta, a escolha dos Ministros do Supremo Tribunal Federal permanece sendo feita pelo Presidente da República, porém, dentre os integrantes de lista tríplice elaborada, no prazo de até um mês após o surgimento da vaga, por um colegiado composto por presidentes dos Tribunais Superiores, Tribunal de Contas da União, PGR e OAB.

Uma vez escolhido pelo Presidente da República e depois de aprovado mediante sabatina pela maioria absoluta do Senado Federal conforme o modelo atual, o Ministro do Supremo Tribunal Federal teria um mandato de dez anos vedada a recondução, tal como ocorre nas principais cortes constitucionais, como o Tribunal Federal Alemão. 
Trata-se de um típico hard case, uma vez que há na confluência entre diversos bens e valores constitucionais, ao qual se destacam, porém, para debate, os princípios republicano e democrático, para análise do papel contramajoritário da corte constitucional e a organização político-administrativa do poder judiciário na Constituição Federal.

A análise da proposta de Emenda Constitucional n³5, que altera o artigo 101 da Constituição Federal para alteração do acesso e permanência dos ministros do Supremo Tribunal Federal à luz dos princípios constitucionais fundamentais do Estado Democrático de Direito Brasileiro, portanto, é o tema posto em debate.

Analisa em que medida a fixação de mandato para os ministros da corte constitucional se demonstra a concretização do princípio democrático e do princípio republicano. Para tanto, verificam-se o papel assumido pela corte constitucional brasileira, os limites do papel do contramajoritário e o princípio democrático e republicano à luz do acesso à referida corte.

\section{A EXPANSÃO DA JURISDIÇÃO CONSTITUCIONAL BRASILEIRA E A ASCENSÃO POLÍTICO-INSTITUCIONAL DO PODER JUDICIÁRIO}

A Constituição Federal de 1988 é marcada pela expansão da jurisdição constitucional, mediante a ampliação do elenco de legitimados para a propositura das ações de controle de constitucionalidade e a criação de novos instrumentos de controle concentrado, garante-se a preservação dos direitos fundamentais do processo político majoritário reservando sua tutela à seara do Poder Judiciário².

Isto porque, com a expansão da jurisdição constitucional, garante-se a proteção da lei fundamental com a preservação de sua hierarquia formal e axiológica perante as normas infraconstitucionais, bem como atos dos demais poderes, mediante atuação das cortes constitucionais, determinando o respeito e a proteção aos direitos fundamentais ${ }^{3}$.

2 Insere-se, portanto, o exercício da jurisdição constitucional orgânica e das liberdades no complexo de mecanismos de natureza normativa, institucional ou processual tendentes a assegurar a plena realização dos direitos fundamentais. COELHO, Rosa Júlia Plá. Mecanismos de Proteção dos Direitos Fundamentais. 1 ed. Brasília: Ordem dos Advogados do Brasil, 2005. p. 34.

3 No Brasil, ampliam-se o objeto e o escopo da jurisdição constitucional por meio da ampliação do elenco de legitimados ativos para a propositura da ação direta de inconstitucionalidade (artigo 103, inciso I a IX), da criação do controle de inconstitucionalidade por omissão (artigo $103 \S 2^{\circ}$ ) com a ação direta e o mandado de injunção (artigo 102 "q"), da previsão da arguição de descumprimento de preceito fundamental (artigo102 §1º), dentre outros. 


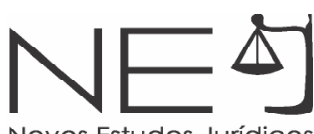

Essa ampliação da competência do Poder Judiciário para o controle de constitucionalidade dos atos emanados pelos poderes públicos e para o crescente exercício das ações abstratas pelos atores políticos e sociais permitiu um processo de juridicização da política, que amplia a influência da Constituição sobre as relações políticas e limita o poder à conformação das escolhas fundamentais da sociedade ${ }^{4}$.

O Poder Judiciário passa a assumir um novo papel, não apenas de proteção dos direitos fundamentais contra ações do Estado, mas de promoção dos direitos individuais, coletivos e difusos, com a exigência de prestações dos poderes públicos o qual, aliado ao acréscimo da demanda social por justiça, resulta na judicialização das questões políticas e sociais e ascensão político-institucional do Poder Judiciário5.

Isto porque, aliada à expansão do controle de constitucionalidade, a ampla incorporação de matérias pela Constituição e a crescente demanda da sociedade por justiça fazem com que as questões políticas e sociais sejam reconduzidas da esfera política à jurídica, pois com a cláusula da inafastabilidade da tutela jurisdicional e o papel de guarda da Constituição, o conhecimento da demanda pelo Poder Judiciário é inevitável.

Por outro lado, a recuperação das liberdades democráticas após a ditadura e das garantias da magistratura, aliada à crise de legitimidade dos poderes públicos, faz com que o Poder Judiciário exerça o papel de controle jurídico das decisões política buscando adequá-las às opções fundamentais da sociedade na Constituição, o que importa em um protagonismo judicial ${ }^{6}$.

4 Como ilustrações, há temas conduzidos ao Supremo Tribunal Federal nos últimos tempos: os limites de investigação das Comissões Parlamentares, a fidelidade partidária, a Reforma da Previdência e a Reforma do Judiciário. Quanto aos direitos fundamentais, há a interrupção da gestação de fetos inviáveis, as pesquisas com células-troncos embrionárias e as políticas públicas de distribuição de medicamentos. Voltar-se-á ao assunto no tópico seguinte.

5 Corresponde à chamada onipotência judicial, decorrente da compreensão que, sendo a Constituição uma norma jurídica presente em todo tipo de conflito, em razão do seu denso conteúdo material, a grande maioria das questões da vida social e política se submetem ao controle pelo Poder Judiciário. SANCHÍS, Luis Pietro. Neoconstitucionalismo Y Ponderación Judicial in CARBONELL, Miguel. Neoconstitucionalismos. Ob. cit. p. 122.

6 O Judiciário deixou de ser um departamento técnico-especializado e se transformou em um verdadeiro poder político, capaz de fazer valer a Constituição e as leis, inclusive em confronto com os outros Poderes. BARROSO, Luís Roberto. Judicialização, Ativismo Judicial e Legitimidade Democrática. Revista Direito do Estado, Salvador, ano 4, n. 13, p. 73, jan./mar. 2009. p. 3. 
Por efeito, com a expansão da jurisdição constitucional, o Poder Judiciário, em especial o Supremo Tribunal Federal, assume um novo papel na promoção dos direitos fundamentais, que aliado ao acréscimo da demanda social por justiça e a recuperação de suas garantias institucionais, resulta na sua ascensão políticoinstitucional e uma expressiva judicialização das questões políticas e sociais ${ }^{7}$.

Por efeito, na última quadra histórica, o Supremo Tribunal Federal tem no controle de constitucionalidade exercido um papel de evidência no controle dos atos dos demais poderes com fins de garantia de proteção das normas constitucionais, em especial no que se refere ao respeito e à concretização dos bens e dos valores fundamentais.

O tema será tratado a seguir.

\section{O ATIVISMO JUDICIAL DA CORTE CONSTITUCIONAL E O PAPEL CONTRAMAJORITÁRIO}

Como visto, a judicialização das questões políticas e sociais decorre do desenho institucional vigente - que apoiado na ampla constitucionalizaçãoinclusão de matérias infraconstitucionais, a adoção do sistema de jurisdição una e o princípio da inafastabilidade da tutela jurisdicional - que conduz ao Poder Judiciário as principais controvérsias da sociedade.

Todavia, no âmbito da jurisdição constitucional, esse exercício do controle das questões políticas e sociais que caberiam precipuamente a deliberação política dos demais Poderes Estatais pode importar na adoção pela Corte Constitucional de uma postura autocontida - de deferência à decisão política majoritária realizada pelos poderes constituídos - ou ativista - de proteção das normas constitucionais criada pelo poder constituinte.

Neste sentido, corresponde ao ativismo judicial, portanto, a atuação intensa e ativa exercida pelo Poder Judiciário no controle dos atos emanados dos demais Poderes Públicos, de forma a garantir a concretização dos valores

$7 \quad$ Corresponde à chamada onipotência judicial, decorrente da compreensão que, sendo a Constituição uma norma jurídica presente em todo tipo de conflito, em razão do seu denso conteúdo material, a grande maioria das questões da vida social e política se submetem ao controle pelo Poder Judiciário. SANCHIS, Luis Pietro. Neoconstitucionalismo Y Ponderación Judicial in CARBONELL, Miguel. Neoconstitucionalismos. Ob. cit. p. 122. 
e fins veiculados pelos preceitos constitucionais e preservar a supremacia axiológica e formal da Constituição e de suas normas ${ }^{8}$.

Sua origem é apontada como no início do século XX com as decisões da Suprema Corte dos Estados Unidos ${ }^{9}$ e na década de 1950 do Tribunal Constitucional Alemão e Italiano ${ }^{10} \mathrm{com}$ a tutela dos direitos fundamentais, notabilizando-se no Brasil nos últimos anos com decisões sobre importantes questões políticas e sociais pelo Supremo Tribunal Federal.

O ativismo judicial envolve a aplicação direta e imediata da Constituição em situações não expressamente contempladas no texto constitucional, diante de omissão ou violação por disciplina normativa pelo legislador ou ato concreto do administrador, com vistas à garantia de proteção ou concretização dos valores e fins constitucionais.

É o que ocorreu no julgamento da ADPF 32, em que o Supremo Tribunal Federal, apesar da inexistência de regra constitucional explícita acerca das uniões homoafetivas, determinou o reconhecimento e a equiparação com as uniões estáveis tradicionais, com fundamento no Princípio da Dignidade da Pessoa Humana e na proteção dos direitos fundamentais. ${ }^{11}$

8 O termo ativismo judicial foi empregado pela primeira vez em 1947 pelo historiador e político Arthur Schlesinger Jr. em artigo na revista Fortune, todavia não há um consenso sobre a sua definição, adotando alguns autores um critério quantitativo - para definir como a atuação demasiada do Poder Judiciário nas decisões dos demais poderes - e outros um critério qualitativo - de forma minimalista ou maximalista - na concretização dos valores constitucionais, que se adota neste trabalho. Sobre o tema, vide: DIMOULIS, Dimitri e LUNARDI, Soraya Gasparetto. Ativismo e Autocontenção Judicial no Controle de Constitucionalidade in: FELLET, André Luiz Fernandes; PAULA, Daniel Grotti de. NOVELINO, Marcelo. As Novas Faces do Ativismo Judicial. São Paulo: Jus Podvim, 2011. p. $460-464$

9 Inicialmente o ativismo judicial foi utilizado de forma conservadora, permitindo a legitimidade para a segregação racial (Dred Scott vs. Sanford em 1857) e invalidação e leis sociais (Lockner v. New York em 1905), porém, no período de 1953 e 1969, sob a presidência de Earl Warren, foram tomadas as decisões progressistas em matéria de direitos fundamentais, como em relação à segregação racial nas escolas públicas (Brown vs. Board of Education em 1954), à incriminação do uso de pílulas anticoncepcionais (Griswold vs. Connecticut em 1965), dentre outras. Sobre o tema, vide: BARROSO, Luís Roberto. A Americanização do Direito Constitucional e seus paradoxos in: Temas de direito constitucional. t. IV. Rio de Janeiro: Renovar, 2009. p. 144 e seguintes.

10 Na Alemanha, o Tribunal Constitucional fixou que a lei fundamental não era ordem neutra de valores, mas que consagrava uma ordem objetiva instrumental à garantia dos direitos fundamentais (BVerfGE7, 198 (205). Porém, assim como na Itália, tentou suavizar os impactos políticos da sua decisão, como advertindo sobre as suas omissões para a sua correção ou advertindo sobre uma revogação em caso de não atuação legislativa retificadora. Sobre o tema, vide: VALLE, Vanice Regina Lírio do. Ativismo Jurisdicional e o Supremo Tribunal Federal. São Paulo: Jiruá, 2009. p. 28

11 Neste caso das uniões homoafetivas (ADPF 132) inexiste regra constitucional expressa que tutele as relações ou prescreva a aplicação do regime de união estável, bem como não há vedação da norma do artigo 226 §3 uma vez que esta, ao tratar de homem e mulher, buscou a superação da desigualdade na relação de casamento e não impedir a aplicação do regime às uniões homoafetivas. Neste sentido, o Supremo Tribunal Federal, com fundamento na dignidade da pessoa humana, aplicou o regime das uniões estáveis a essa nova modalidade de família. Sobre o tema, vide: BARROSO, Luís Roberto. O Reconhecimento Jurídico das Relações Homoafetivas no Brasil. Revista do Ministério Público do RJ. p. 155 e ss. n. 27. 
Abrange a invalidação de atos normativos emanados do Poder Legislativo ou Administrativo de constitucionalidade discutível, ou seja, com adoção de critérios menos rígidos do que aqueles em que inexiste patente e ostensiva violação da Constituição, com vista à preservação da hierarquia das normas constitucionais. É o verificado no caso da ADIN 3685, em que a Emenda Constitucional 52, que disciplinava coligações eleitorais impondo sua aplicação imediata, violava a anterioridade anual da lei eleitoral, que embora não fosse cláusula pétrea, o Supremo Tribunal Federal reconheceu tal status com fins de garantir a preservação e a eficácia da referida norma constitucional. ${ }^{12}$

Por fim, compreende a imposição de condutas ou de abstenções ao Poder Público capazes de impedir violação ou garantir a concretização de direitos e fins constitucionais, em especial mediante o controle judicial sobre os programas de políticas públicas de forma a assegurar o acesso a prestações a bens e serviços essenciais. É o que foi decidido na ADPF 45/DF, cujo Presidente da República vetou norma da lei de diretrizes orçamentárias que garantia recursos mínimos para ações e serviços públicos de saúde e o Supremo Tribunal Federal entendeu que, embora haja espaço de conformação legislativa e discricionariedade administrativa, elas não podem ser utilizadas para neutralizar a eficácia dos direitos sociais. ${ }^{13}$

No Brasil, o ativismo judicial está diretamente relacionado com a crise de legitimidade e representatividade democrática, que gera um descolamento entre os órgãos representativos e a sociedade, e a incapacidade ou o desinteresse em atender as demandas sociais, produzindo um deslocamento do exercício da cidadania para o âmbito do Poder Judiciário.

12 Neste caso da verticalização (ADIn 3685), o artigo $2^{\circ}$ da Emenda Constitucional 52 de 8 de Março de 2006 alterava o artigo $17 \S 1^{\circ}$ da Constituição da República, fixando data para alteração, em violação ao princípio da anterioridade anual da lei eleitoral (CF, art. 16). O Supremo Tribunal Federal, para proteger a norma constitucional, que embora não tivesse uma violação frontal perderia sua eficácia, declarou inconstitucional a emenda constitucional, dando à norma do artigo 16 o status de cláusula pétrea, embora não se enquadre ao rol de cláusulas elencadas na Constituição. Sobre este tema, consulte-se: GALLACCI, Fernando Bernardi. O STF e as Cláusulas Pétreas: O ônus argumentativo em prol da governabilidade? São Paulo: SBDP, 2011. p. 25-27.

13 O Supremo Tribunal Federal na ADPF 45/DF se manifestou, no sentido, que não obstante a formulação e a execução das políticas públicas dependam de opções políticas a cargo daqueles que, por delegação popular, receberam investidura em mandato eletivo, cumpre reconhecer que não se revela absoluta, neste domínio, a liberdade de conformação do legislador, nem a de atuação do Poder Executivo, de modo que não podem proceder com a clara intenção de neutralizar, comprometendo-a, a eficácia dos direitos sociais, econômicos e culturais. Sobre o tema, em seus limites e possibilidades, vide: MOURA, Emerson Affonso da Costa. Do Controle Jurídico ao Controle Social: Parâmetros a Efetividade dos Direitos Sociais. Revista de Direito Constitucional e Internacional - IBDC. Volume 77. Dez 2011. 
A redução da deliberação política ao processo eletivo ${ }^{14}$, a histórica e perniciosa influência econômica dos agentes políticos sobre o eleitor ${ }^{15}$ e a captação dos agentes políticos por grupos de interesse ${ }^{16}$ conduzem a um distanciamento entre representante e representado, promovendo estreitamento do debate político que se transfere para os órgãos judiciários. O desinteresse dos atores políticos em atender questões de interesse social em que há um desacordo moral razoável na comunidade, de forma a evitar os desgastes promovidos pelo debate e os riscos da responsabilização política nas eleições, torna o Poder Judiciário uma instância decisória política de questões polêmicas ${ }^{17}$. O processo de hipertrofia legislativa com a explosão de legislação infraconstitucional e regulamentação infralegal, bem como a atecnicidade da produção legislativa com a criação de conceitos jurídicos indeterminados desencadeiam a ampliação dos conflitos na sociedade e na litigiosidade, bem como o potencial criativo e a margem de discricionariedade do Judiciário ${ }^{18}$.

As omissões legislativas na regulamentação de preceitos impostas pela Constituição que impede o exercício dos direitos pelos representados, aliadas à instituição de mecanismo próprio de controle de constitucionalidade pela via concentrada e a utilização de ação constitucional na via incidental, impõem a intervenção judicial na decisão política.

14 Trata-se de fenômeno com fundamentos diversos, que variam desde a impossibilidade de participação devido às condições de pobreza extrema e baixo nível de educação de grande parte da população, da dificuldade de acesso às informações sobre as questões políticas e a falta de tempo para debater e manifestar sobre tais assuntos, até mesmo a descrença de que sua participação seja capaz de influenciar na ação pública. BARCELLOS, Ana Paula de. Papéis do Direito Constitucional no Fomento do Controle Social Democrático: Algumas Propostas Sobre o Tema da Informação in RDE ano 3. N. 12. Out/dez 2008. p. 82-84.

15 Remonta ao período colonial brasileiro a adoção de um modelo patrimonialista marcado pelo predomínio da corrupção, nepotismo e uso do poder econômico que se exterioriza até os dias atuais na corrupção persistente e nas políticas paternalistas que marcam a política brasileira. Sobre o tema, vide: FAORO, Raymundo. Os Donos do Poder. 15 ed. São Paulo: Editora Globo, 2000.

16 A captura de partidos e candidatos por grupos de interesse que patrocinam as campanhas eleitorais para posteriormente cobrar favores, por meio da satisfação de políticas distributivas a seu favor, é uma das formas de captura, mas não único meio de influência dos grupos de interesse, em especial, econômicos, na captura dos membros do Congresso. Sobre o tema, vide: MANCUSO, Wagner Pralon. O Lobby da indústria no Congresso Nacional. São Paulo: EDUSP, 2007. p. 110.

17 O ativismo judicial é exercido em contextos de inércia intencional pelos demais poderes de Estado. Em casos que são politicamente custosos com temas profundamente custosos sem perspectiva de consenso na sociedade, como as uniões homoafetivas, ditadura militar e aborto, as instâncias democráticas abrem espaço para atuação ativista, repassando os custos políticos para os tribunais que não passam pelo crivo do voto popular após suas decisões. VIEIRA, José Ribas; CAMARGO, Margarida Maria Lacombe e SILVA, Alexandre Garrido. O Supremo Tribunal Federal como arquiteto constitucional: A judicialização da política e o ativismo judicial. In: Anais do I Forum de Grupos de Pesquisa em Direito Constitucional e Teoria dos Direitos, 2009. p. 44-45.

18 A hipertrofia do direito legislado e a produção de leis vagas reforçam e alimentam a possibilidade do direito judicial transferindo para o Poder Judiciário a decisão sobre conflitos que caberiam ser dirimidos no âmbito político. CAMPILONGO, Celso Fernandes. O Direito na sociedade complexa. São Paulo: Max Limonad, 2000. p. 87. 
Por efeito, neste cenário de crise das instâncias democráticas, a rigor, o papel ativo do Poder Judiciário, em especial do Supremo Tribunal Federal, na realização dos valores e fins constitucionais, não viola o princípio da separação dos poderes, mas é capaz de contribuir com o processo democrático ao garantir os seus pressupostos materiais, pela concretização dos direitos fundamentais.

Porém, o Poder Judiciário não pode atuar a título de proteção dos direitos fundamentais como poder constituinte permanente, moldando a Constituição de acordo com as suas preferências políticas, sem a devida legitimidade e responsabilidade política em evidente violação ao princípio majoritário e ao processo democrático. ${ }^{19}$

Há princípios sensíveis à democracia, a saber, questões notadamente políticas que se sujeitam à vontade da maioria e, portanto, estão a rigor fora da ingerência do Poder Judiciário, mas também há princípios insensíveis ao princípio majoritário, questões relativas à própria proteção da pessoa humana, as quais se sujeitam ao controle judicial ${ }^{20}$.

Por esta razão, sucessivamente os poderes constituídos têm buscado formas de limitar a atuação da corte constitucional, de forma a garantir uma menor ingerência no que se refere às questões políticas e sociais, o que parece se ligar ao princípio democrático e aos limites naturais que devem ocorrer ao papel contramajoritário da corte.

O tema será tratado a seguir.

\section{O PRINCÍPIO DEMOCRÁTICO E OS LIMITES AO PAPEL CONTRAMAJORITÁRIO}

Como visto, o Estado Democrático de Direito se erige sob a dialética entre constitucionalismo - enquanto técnica de limitação do poder como forma de garantia dos direitos básicos do cidadão ${ }^{21}$ - e democracia - enquanto soberania

19 Sarmento, Daniel. A proteção judicial dos direitos sociais. In: ; Souza Neto, Cláudio Pereira de (orgs.). Direitos sociais: fundamentos, judicialização e direitos sociais em espécie. Rio de Janeiro: Lumen Juris, 2008.

20 Dworkin, Ronald. Ob. cit., p. 129 e 224.

21 CANOTILHO, José Joaquim Gomes. Direito constitucional e teoria da constituição. 3. ed. Coimbra: Almedina, 2000, p. 47. 
popular e vontade da maioria 22 - e sob a tensão imanente entre os bens constitucionais e o governo democrático.

De um lado, portanto, cabe à Constituição garantir as condições necessárias ao processo democrático, mediante a garantia das condições procedimentais e da reserva do espaço próprio do pluralismo político, assegurando um ambiente para o adequado funcionamento da deliberação política, inclusive com a garantia das liberdades fundamentais essenciais ao exercício democrático ${ }^{23}$.

Porém, por outro, abrange preservação de um conjunto de valores e objetivos que traduzem um compromisso com a transformação social e não permitem que os poderes constituídos disponham livremente dos bens essenciais da sociedade, gerando o esvaziamento da eficácia das normas constitucionais a título de exercício da democracia. ${ }^{24}$

Assim, se cabe aos poderes constituídos o processo de concretização das normas constitucionais por meio da conformação legislativa e da discricionariedade administrativa; por outro, os direitos fundamentais, fruto do poder constituinte originário, não se sujeitam a um espaço ilimitado de decisão do governo democrático na sua proteção, promoção e restrição.

Neste sentido, a lei fundamental, portanto, veicula consensos mínimos para proteção dos indivíduos e funcionamento do regime democrático, protegendo os direitos fundamentais do exercício do princípio majoritário e das decisões

22 Na teoria contemporânea da Democracia confluem três grandes tradições do pensamento político: a teoria clássica de Aristóteles, da Democracia, como Governo do povo, de todos os cidadãos, ou seja, de todos aqueles que gozam dos direitos de cidadania; a teoria medieval, de origem Romana, que identifica Democracia com soberania conforme o poder supremo deriva do povo e se torna representativo ou deriva do príncipe e se transmite por delegação do superior para o inferior; e a teoria moderna, de Maquiavel, em que a Democracia é o governo genuinamente popular. BOBBIO, Norberto Bobbio; MATTEUCCI, Nicola; PASQUINO, Gianfranco. Dicionário de Política. Brasília: Editora Universidade de Brasília, 1998. p. 320.

23 A Constituição não pode e nem deve ter a pretensão de suprimir a deliberação legislativa majoritária, mas deve proteger as condições procedimentais que permitam o desenvolvimento do processo político deliberativo. Assim, a Constituição da República de 1988 veiculou o princípio democrático e majoritário (Art. $1^{\circ}$ caput), garantiu o pluralismo político (Art. $1^{\circ}$ inciso V), a inserção como cláusula pétrea tendente a abolir o voto direto, secreto, universal e periódico e a forma federativa (art. $60 \S^{\circ}$ ), dentre outros. No viés procedimentalista, vide: ELY, John Hart. Democracia e Desconfiança: Uma teoria do controle judicial de constitucionalidade. São Paulo: Martins Fontes, 2011 e HABERMAS, Jurgen. Direito e democracia entre facticidade e validade. Rio de Janeiro: Tempo Brasileiro, 1997.

24 Isto porque a ideia de democracia não se limita ao governo da maioria, porém compreende outros princípios e o respeito aos direitos da minoria. Assim, enquanto o processo político majoritário se move por interesses, a lógica democrática se inspira em valores, restando ao Poder Judiciário preservar diante da soberania popular e do governo da maioria a limitação do poder e os direitos fundamentais. BARROSO, Luís Roberto. Curso de direito constitucional contemporâneo. 2. ed. Rio de Janeiro: Saraiva, 2009. P. 382-91. 
proferidas por maiorias políticas ocasionais, inclusive mediante o controle de deliberações políticas que o violem ${ }^{25}$. $\mathrm{Na}$ ordem jurídica, em que há um sistema de Controle de Constitucionalidade das leis e dos atos normativos, as tensões são resolvidas pelo exercício da jurisdição constitucional ${ }^{26}$ que tutela a soberania popular com a preservação das condições procedimentais do exercício democrático e os direitos fundamentais pela proteção à manifestação da vontade da maioria ${ }^{27}$. De tal sorte, cabe ao Poder Judiciário garantir a proteção e a promoção dos direitos fundamentais mediante o controle dos atos dos demais poderes públicos que violem ou não os concretize, sem que isto, necessariamente, resulte em violação do princípio democrático, mas, inclusive, exteriorize a proteção dos pressupostos básicos da democracia.

Porém, em um contexto democrático, marcado pela liberdade e igualdade dos indivíduos, cabe às maiorias legislativas respeitar os direitos fundamentais, por meio da garantia da preservação da autonomia do indivíduo, para desenvolver suas capacidades morais - de ter sua concepção de bem e de justiça - e as faculdades de razão - de juízo e de pensamento ${ }^{28}$. Por efeito, vedase que, no exercício da conformação legislativa com a regulação dos preceitos constitucionais, sejam realizadas escolhas morais, que inviabilizem a existência da pluralidade de concepções morais dos indivíduos, dentro do consenso mínimo veiculado pela Constituição, garantindo pluralismo na sociedade e inserção de todos no processo democrático ${ }^{29}$.

25 A Constituição deve proteger e as cortes judiciais implementar os direitos e os princípios que realizem os valores de justiça, liberdade e igualdade. No viés substancialista, vide: RAWLS, John. Uma Teoria de Justiça. Belo Horizonte: Editora Martins, 2008 e DWORKIN, Ronald. Levando os Direitos a Sério. Belo Horizonte: Editora Martins Fontes, 2010.

26 Cabe a todo órgão que possua o status de realizar a jurisdição constitucional zelar pela aplicação das normas constitucionais, inclusive, se for necessário, contra a vontade da maioria. HARBELE, Peter. El Tribunal Constitucional Federal como modelo de uma jurisdicción constitucional autônoma in: HARBELE, Peter. Estudios sobre la jurisdicional constitucional. México: Porrúa, 2005. p. 166.

27 De forma que a vontade da maioria momentânea - do poder governante - não se sobreponha sobre a vontade da maioria permanente - do poder constituinte originária. VITAL, Moreira. Princípio da Maioria e Princípio da Constitucionalidade: Legitimidade e Limites da Justiça Constitucional in: Legitimidade e Legitimação da Justiça Constitucional. Coimbra: Coimbra Editora, 1995. p. 179.

28 RAWLS, John. Op. cit. p. 277 e p. 365-380

29 Por exemplo, se no crime de injúria qualificado se protegem as minorias sujeitas à preconceito (Art. $140 \S 3^{\circ}$ ), a falta de inclusão da opção sexual no tipo penal denota a exclusão de uma escolha moral - outras formas de sexualidade - pela sua não tutela em favor da imposição de outra. 
Da mesma forma, não significa que as questões sobre direitos devam ser decididas por um Poder Judiciário, uma vez que a resposta alcançada não será adequada, por não respeitar as capacidades morais e políticas dos cidadãos, bem como não será a mais correta, em razão do desacordo moral existente no seio da comunidade $^{30}$. Em um Estado Democrático de Direito, a Constituição não pode ocupar todo espaço jurídico, inviabilizando a expressão da soberania popular ou impondo um projeto social às próximas gerações. ${ }^{31}$

Tampouco, em um cenário de pluralismo social e de complexidade da vida, a interpretação constitucional restringe-se ao processo judicial e à corte constitucional. ${ }^{32}$ Embora represente um grande potencial na concretização dos direitos ${ }^{33}$, é impossível desconsiderar na atuação ativista do Poder Judiciário a existência dos excessos, ${ }^{34}$ bem como o risco da consolidação de uma hegemonia judicial ou o perigo do exercício de preferências políticas

30 Por exemplo, novamente no julgamento da interrupção da gestação de feto anencéfalo quando a Corte decidiu fixar o momento que começa a vida, impondo uma escolha moral sobre as variadas existentes na matéria, tanto do ponto de vista jurídico, filosófico, científico e religioso.

31 Ao contrário, o direito constitucional deve atuar no aprimoramento do processo democrático, permitindo que os cidadãos decidam os valores e os bens jurídicos a serem alcançados pelo grupo social em um contexto de livre circulação de ideias e de informações. Sobre a democracia nesta vertente: SouZA NETO, Cláudio Pereira de. Deliberação pública, constitucionalismo e cooperação democrática. In: SARMENTO, Daniel (org.). Filosofia e teoria constitucional contemporânea. Rio de Janeiro: Lumen Juris, 2009. p. 79-112.

32 A atual interpretação constitucional é marcada pela participação de novos atores em um círculo que antecede o processo judicial, em que os poderes públicos, os cidadãos, bem como as forças públicas que participam do processo social, são, potencialmente, intérpretes da Constituição. Vide: HärBelE, Peter. Hermenêutica constitucional. A sociedade aberta dos intérpretes da Constituição: contribuição para a interpretação pluralista $e$ procedimental da Constituição. Porto Alegre: Sergio Antonio Fabris Ed., 2002.

33 É importante, todavia, considerar-se os limites das normas constitucionais, evitando a falsa concepção de que apenas com o Direito será possível alcançar a superação da pobreza, da desigualdade e da falta de democracia. A ficção de que a norma pode tudo e a ambição de salvar o mundo com papel e tinta podem conduzir a um direito constitucional desprendido da vida real. LOPES, José Reinaldo de Lima. Judiciário, democracia, políticas públicas cit., p. 260. BARRoso, Luís Roberto. Curso de direito constitucional... cit., p. 45.

34 Como exemplo, pode-se citar as ações que versam sobre tratamentos médicos exorbitantes no exterior, medicamentos não essenciais, como Viagras, além de próteses, aparelhos de audição, ultrassom, próteses, tratamentos psicológicos de adolescentes carentes, transplantes de medula, marca-passos e afins. Sobre o tema, vide: HofFMAN, Florian F.; Bentes, Fernando R. N. M. A litigância judicial dos direitos sociais no Brasil: uma abordagem empírica. In: SARmento, Daniel; Souza Neto, Cláudio Pereira (orgs.). Direitos sociais fundamentos, judicialização e direitos sociais em espécie. Rio de Janeiro: Lumen Juris, 2008. p. 391-400. 
Isto porque, no sistema representativo, o campo adequado para o debate sobre a conveniência da decisão política é a deliberação pública e o controle precípuo pela sociedade por meio de mecanismos que variam desde a mobilização da sociedade civil na fiscalização da gestão pública até a responsabilização política por meio de eleições competitivas. ${ }^{35}$

Há de se considerar que o papel contramajoritário da corte constitucional há de ser exercido de forma excepcional como proteção aos bens e valores constitucionais apenas em caso de violação pela deliberação majoritária e não quando se referir exclusivamente a um espaço legítimo de atuação democrática dos atores eleitos.

Isto porque, inevitável que enquanto os representantes dos poderes legislativos e executivos são regularmente eleitos e dotados de uma legitimidade ordinária ou imediata por meio do processo democrático, a atuação da jurisdição constitucional assume uma legitimidade mediata da própria proteção do regime jurídico-constitucional.

Por efeito, assim como não se pode negar a legitimidade constitucional da função contramajoritária da corte na invalidação dos atos dos demais poderes públicos, igualmente não se deve recusar que tal função deve ser exercida com cautela, visto que as deliberações políticas são frutos de ao menos em tese uma legitimidade democrática.

Nesta tensão entre expansão dajurisdição constitucional pela lei fundamental e um protagonismo judicial, em especial da corte constitucional reforçado por um acréscimo de ingerência nos atos dos demais poderes que deve ser inserida a análise da respectiva emenda constitucional, que busca alterar o regime de acesso à corte constitucional.

O tema será tratado a seguir.

35 Sobre as técnicas de participação formais e informais da sociedade na atividade estatal e a sua atuação como instrumentos de legitimação do poder do Estado, consultar: MoREIRA NETO, Diogo de Figueiredo. Direito da participação política. Rio de Janeiro: Renovar, 1992. Vide também: Justino de OliveIRA, Gustavo Henrique. Participação administrativa. In: OsóRıo, Fábio Medina; Souto, Marcos Juruena Villela. Direito administrativo e estudos em homenagem a Diogo de Figueiredo Moreira Neto. Rio de Janeiro: Lumen Juris, 2006. p. 401-428. 


\section{O PRINCÍPIO DEMOCRÁTICO E REPUBLICANO À LUZ DO ACESSO E DA PERMANÊNCIA DOS MINISTROS NO SUPREMO TRIBUNAL FEDERAL}

A proposta de emenda constitucional se insere em um momento de tensão entre a corte constitucional e os demais poderes públicos, decorrente pela adoção de uma postura de ativismo judicial pelo Supremo Tribunal Federal, bem como pela indicação de uma maioria dos ministros atuais da corte por determinado grupo político ${ }^{36}$. Inevitável que a ampla constitucionalização dos temas políticos e sociais e da expansão da jurisdição constitucional, aliada à tal postura ativista da corte constitucional, amplia a tensão entre constitucionalismo e democracia, porém a alteração do regime de acesso e de permanência dos ministros da corte constitucional deve ser tido à luz da própria ordem constitucional.

Uma vez que o Supremo Tribunal Federal exerce uma função contramajoritária - de proteção dos bens e valores constitucionais contra a deliberação da vontade majoritária-, as reformas introduzidas no Poder Judiciário devem ser consideradas não como forma de esvaziamento deste poder, mas de aperfeiçoamento perante o Estado Democrático de Direito.

Não se pode negar que a Constituição Federal de 1988, ao adotar ao lado do princípio federativo e democrático o princípio republicano, forma um núcleo essencial da Constituição, que garante uma identidade - dano de especificidade em relação a outros regimes político-jurídicos - e estrutura -, organizando o modus operandi do Estado Constitucional. ${ }^{37}$

36 Segundo dados do próprio Supremo Tribunal Federal: Michel Temer 1 Ministros; Dilma Roussef 5 Ministros Luiz Inácio Lula da Silva 8 Ministros; Fernando Henrique Cardoso 3 Ministros; Itamar Augusto Cautiero Franco Ministros; Fernando Affonso Collor de Mello 4 Ministros; José Sarney 5 Ministros; João Baptista de Oliveira Figueiredo 9 Ministros; Ernesto Geisel 7 Ministros; Emílio Garrastazu Médici 4 Ministros; Artur da Costa e Silva 4 Ministros; Humberto de Alencar Castelo Branco 8 Ministros; João Belchior Marques Goulart 2 Ministros; Jânio da Silva Quadros 1 Ministros; Juscelino Kubitschek de Oliveira 4 Ministros; Nereu de Oliveira Ramos; 1 Ministros; Eurico Gaspar Dutra 3 Ministros; José Linhares 3 Ministros; Getúlio Dorneles Vargas21 Ministros; Washington Luís Pereira de Sousa 4 Ministros; Arthur da Silva Bernardes 5 Ministros; Epitácio da Silva Pessôa 3 Ministros; Delfim Moreira da Costa Ribeiro 1 Ministros; Wenceslau Braz Pereira Gomes 4 Ministros; Hermes Rodrigues da Fonseca 6 Ministros; Nilo Peçanha 2 Ministros; Affonso Augusto Moreira Penna 2 Ministros; Francisco de Paula Rodrigues Alves 5 Ministros; Manoel Ferraz de Campos Salles 2 Ministros; Manoel Victorino Pereira 3 Ministros; Prudente José de Moraes Barros 7 Ministros; Floriano Vieira Peixoto 15 Ministros; Manoel Deodoro da Fonseca 15 Ministros; Disponível em: http://www.stf.jus.br/portal/ministro/ministro.asp?periodo=stf\&tipo=quadro Acesso em 04.10.2017.

37 CANOTILHO, José Joaquim Gomes. Direito Constitucional. Coimbra: Almedina, 1992. p. 349. 
Sob tal viés, a adoção de um regime republicano constitucional implica na adoção não apenas de uma forma de governo, ao qual os cidadãos possam em igualdade de condições ou sem distinções de qualquer natureza serem investidos ao poder público e ter o acesso aos cargos públicos em geral.

Isto implicaria estreitamento do princípio republicano ${ }^{38}$ ao princípio de acesso aos cargos e aos empregos públicos ${ }^{39}$ e dos cargos políticos ${ }^{40}$, que corresponde antes a uma irradiação de tal preceito do que propriamente dito esgota todo conteúdo que irá assumir no Estado Democrático de Direito.

Impõe o princípio republicano a existência de uma estrutura políticoorganizatória capaz de garantir as liberdades civis e políticas, bem como a própria elaboração de um catálogo de liberdades, que preveja não apenas os direitos fundamentais individuais, mas igualmente os direitos de participação política. ${ }^{41}$

Demanda oreconhecimento dalegitimaçãodopoderpolíticoconsubstanciada no princípio democrático em que a soberania reside no povo e, portanto, a opção fundamental pela eletividade, colegialidade, temporariedade e pluralidade como princípios ordenadores do acesso aos cargos públicos. ${ }^{42}$

Note, portanto, que se espraia o princípio republicano no regime constitucional de forma equidistante dos critérios da designação, da hierarquia e da vitaliciedade, que devem marcar apenas os regimes monárquicos ainda que parlamentaristas constitucionais como o Reino Unido. Neste viés, observa-se uma tensão no que se refere ao modelo de acesso e permanência dos ministros do Supremo Tribunal Federal, já que há a ausência de elementos fundamentais do princípio republicano - eletividade e temporariedade -, o que impõe um ônus argumentativo maior que justifique a manutenção deste modelo.

Sob tal viés, previu a Constituição Federal de 1988 como fruto de um processo de redemocratização e após um amplo período de ditadura militar com repressão dos direitos fundamentais do cidadão e sucessiva limitação dos

38 BRASIL, Constituição da República Federativa do Brasil de 05 de outubro de 1988. Art. 1.

39 BRASIL, Constituição da República Federativa do Brasil de 05 de outubro de 1988. Art. 37 I.

40 BRASIL, Constituição da República Federativa do Brasil de 05 de outubro de 1988. Art. 14.

41 MENDES, Gilmar Ferreira; COELHO, Inocencio Mártires; BRANCO, Paulo Gustavo Gonet. Curso de Direito Constitucional. São Paulo: Saraiva, 2009. p. 169.

42 MENDES, Gilmar Ferreira; COELHO, Inocencio Mártires; BRANCO, Paulo Gustavo Gonet. Op. cit. p. 169. 
poderes da corte constitucional ${ }^{43}$ - como as aposentadorias compulsórias - e previu modelo estável de acesso aos ministros do Supremo.

Por efeito, dispôs que o Supremo Tribunal Federal seria composto de 11 ministros, escolhidos dentre cidadãos com mais de trinta e cinco e menos de sessenta e cinco anos de idade, de notável saber jurídico e reputação ilibada ${ }^{44}$ que seriam nomeados pelo Presidente da República após a escolha pela maioria absoluta do Senado Federal ${ }^{45}$.

Assim manteve modelo que não é recente na história constitucional brasileira, embora tendesse em um primeiro momento pela não imposição de limite de idade para o cargo como na Constituição de $1891^{46}$, que depois foi alterado pela fixação de idade mínima e máxima para o seu exercício, que ocorreu na Constituição de $1934^{47}$. Porém, é tradição na história constitucional brasileira a nomeação livre pelo Presidente da República conforme além daquelas cartas, como foi prevista na Constituição de $1937^{48}$, tendo por exceção apenas a Constituição Imperial de 1824, que os selecionavam de juízes letrados. ${ }^{49}$

43 Dentre outros, o ato institucional $n^{\circ} 5$ suspendeu três ministros do Supremo Tribunal Federal e o ato institucional $n^{\circ} 6$ reduziu o número de juízes na corte constitucional de 16 para 11.

44 BRASIL, Constituição da República Federativa do Brasil de 05 de outubro de 1988. Art. 111.

45 BRASIL, Constituição da República Federativa do Brasil de 05 de outubro de 1988. Art. 111 Parágrafo Único.

46 BRASIL, Constituição da República dos Estados Unidos do Brasil de 24 de fevereiro de 1891. Art. 55 e 56.

47 BRASIL, Constituição da República dos Estados Unidos do Brasil de 16 de julho de 1934. Art. 74.

48 BRASIL, Constituição da República dos Estados Unidos do Brasil de 16 de julho de 1934. Art. 98.

49

BRASIL, Constituição Politica do Imperio do Brazil de 25 de março de 1824. Art. 163. 
Ainda que não seja um modelo amplamente adotado pela Constituição Federal de 1988, já que parte da composição dos ministros do Superior Tribunal de Justiça ${ }^{50}$, dos Tribunais Regionais Federais, dos Estados, e do Distrito Federal ${ }^{51}$ e do Tribunal de Contas da União ${ }^{52}$, decorre de uma nomeação pelo chefe do executivo a partir de listas tríplices.

Sob tal viés, parece que a opção do constituinte originário de garantir acesso aberto à corte constitucional atende plenamente o princípio republicano ao permitir ampla participação de qualquer cidadão brasileiro na condução ao Supremo Tribunal Federal, já que órgão de cúpula do Poder Judiciário, o que atende por simetria o acesso à chefia dos outros Poderes.

Por efeito, a proposta de emenda constitucional de determinar uma lista tríplice formada por um colegiado composto por presidentes dos Tribunais Superiores, Tribunal de Contas da União e o Procurador-geral da República, parece reduzir o acesso à corte constitucional e esvaziar uma atribuição historicamente do Presidente da República.

Poderia se arguir que o processo proposto pela Emenda Constitucional teria caráter democrático, já que por meio de elaboração da lista tríplice permitiria a representação popular na formação da referida decisão, porém se observa a participação apenas dos Tribunais, da Procuradoria Geral da República e da Ordem dos Advogados do Brasil.

50 BRASIL, Constituição da República Federativa do Brasil de 05 de outubro de 1988. "Art. 104. O Superior Tribunal de Justiça compõe-se de, no mínimo, trinta e três Ministros. Parágrafo único. Os Ministros do Superior Tribunal de Justiça serão nomeados pelo Presidente da República, dentre brasileiros com mais de trinta e cinco e menos de sessenta e cinco anos, de notável saber jurídico e reputação ilibada, depois de aprovada a escolha pela maioria absoluta do Senado Federal, sendo: I - um terço dentre juízes dos Tribunais Regionais Federais e um terço dentre desembargadores dos Tribunais de Justiça, indicados em lista tríplice elaborada pelo próprio Tribunal;

51 BRASIL, Constituição da República Federativa do Brasil de 05 de outubro de 1988. Art. 94. Um quinto dos lugares dos Tribunais Regionais Federais, dos Tribunais dos Estados, e do Distrito Federal e Territórios será composto de membros, do Ministério Público, com mais de dez anos de carreira, e de advogados de notório saber jurídico e de reputação ilibada, com mais de dez anos de efetiva atividade profissional, indicados em lista sêxtupla pelos órgãos de representação das respectivas classes. Parágrafo único. Recebidas as indicações, o tribunal formará lista tríplice, enviando-a ao Poder Executivo, que, nos vinte dias subseqüentes, escolherá um de seus integrantes para nomeação.

52 BRASIL, Constituição da República Federativa do Brasil de 05 de outubro de 1988. Art. 73. O Tribunal de Contas da União, integrado por nove Ministros, tem sede no Distrito Federal, quadro próprio de pessoal e jurisdição em todo o território nacional, exercendo, no que couber, as atribuições previstas no art. 96 . $\S 2^{\circ}$ Os Ministros do Tribunal de Contas da União serão escolhidos: I - um terço pelo Presidente da República, com aprovação do Senado Federal, sendo dois alternadamente dentre auditores e membros do Ministério Público junto ao Tribunal, indicados em lista tríplice pelo Tribunal, segundo os critérios de antigüidade e merecimento; [...]. 
Neste sentido, se a aplicação plena do modelo republicano importaria em tese na assunção do seu caráter de eletividade com a deliberação popular de escolha dos ministros do Supremo Tribunal Federal, há de se admitir que no modelo adotado pela ordem brasileira e outros Estados a composição dessa lista tríplice não representa realização deste valor.

Ao contrário, retira-se a possibilidade de indicação para a composição do chefe do Poder Executivo, legitimamente eleito, para escolher o Ministro do Supremo Tribunal Federal que está sujeito aos checks and balances oriundos do próprio princípio da separação e do equilíbrio dos poderes, no que se refere ao controle recíproco exercido pelos poderes públicos.

Apenas por meio da sabatina - com arguição pública pela Comissão de Constituição, Justiça e Cidadania e depois aprovação pela maioria absoluta pelo Senado Federal - que o ministro será nomeado pelo Presidente da República em pleno princípio democrático, já que dependerá de ato de ambos poderes, cujos seus representantes são legitimamente eleitos. Sob tal viés, a mudança proposta pela PEC no acesso aos Ministros do Supremo Tribunal Federal - mediante prévia lista tríplice - não parece atender ao critério de eletividade decorrente do princípio republicano, pois impõe sujeição à indicação por representantes não eleitos popularmente ao revés daquele investido diretamente pela sociedade.

Embora se concorde ou não com as nomeações realizadas pelo chefe do Poder Executivo acerca dos Ministros do Supremo Tribunal Federal, há de se reconhecer que o princípio republicano representa um estado de espírito coletivo, que transcende qualquer antagonismo ou tensões existentes seja político-partidária, econômico-social e afins. ${ }^{53}$ Por efeito, compete ao Presidente da República a nomeação dos respectivos ministros, inclusive porque se sujeitará às consequências jurídicas e às responsabilidades políticas, que abrangem desde os mecanismos formais, como o impeachment, até os informais, como o accountability.

53 LEWANDOWSKI, Enrique Ricardo. Reflexões em torno do princípio republicano. Revista da Faculdade de Direito da Universidade de São Paulo v. 100 p. 197. jan./dez. 2005 
Outra questão, todavia, é o mandato dos Ministros da Corte Constitucional, pois o processo de nomeação é para cargo vitalício ${ }^{54}$, tanto que o Ministro do Supremo Tribunal Federal só perderá o cargo por renúncia, aposentadoria compulsória mediante limite de idade ou processo de impeachment.

Não se deve negar que, embora não exista mandato para o exercício da função de Ministro do Supremo Tribunal Federal, sempre houve prazo médio de permanência no cargo - no período 1946-1987 não tem sido superior a oito anos; 1989-2006, de onze anos - porém alguns permaneceram por mais de 20 anos. ${ }^{55}$ Porém, no que tange à temporariedade, há de se reconhecer que é pressuposto de qualquer Estado Republicano, ao revés do Estado Aristocrático, como afirmado por um próprio Ministro do Supremo Tribunal Federal, mais do que a eletividade dos cargos públicos, a temporariedade dos seus mandados e a possibilidade de sua responsabilização. ${ }^{56}$

Neste viés é que se liga o princípio republicano com o democrático, pois o sistema representativo pressupõe ainda a existência de mecanismos que estabeleçam o predomínio da vontade da maioria, com a garantia de que as minorias encontrem expressão no plano político mediante diversos mecanismos - pluripartidarismo, liberdades civis e outros. ${ }^{57}$

Neste viés, a fixação de um mandato para Ministros do Supremo Tribunal Federal atende ao princípio republicano - que impõe temporariedade na delimitação do exercício dos cargos públicos - e ao princípio democrático ao permitir a representatividade conforme as alternâncias políticas na chefia do poder executivo.

Há de se ressaltar que a experiência constitucional comparada demonstra a importância de mandato, em especial, nas cortes constitucionais tidas como referência mundial, tal qual no Tribunal Constitucional Federal Alemão, onde há mandato de 12 anos e na Corte Constitucional da Itália, onde há mandato de 9 anos. Além disto, no próprio Conselho Constitucional da França, após

54 BRASIL, Constituição da República Federativa do Brasil de 05 de outubro de 1988. Art. 95. BRASIL, Regimento Interno do Supremo Tribunal Federal. Art. 16.

55 CANOTILHO, J. J. Gomes. Comentários à Constituição do Brasil. São Paulo: Saraiva/Almedina, 2013. p. 2865.

56 LEWANDOWSKI, Enrique Ricardo. Op. cit. p. 193.

57 LEWANDOWSKI, Enrique Ricardo. Op. cit. p. 195. 
reformas, um terço dos assentos são renovados a cada três anos e no Tribunal Constitucional Português o mandato é de 9 anos, igualmente sem recondução, o que permite uma maior representatividade nas referidas cortes constitucionais.

CONCLUSÃO

Como visto, parece que a proposta de Emenda Constitucional $n^{\circ} 35$ de 2015, no que se refere à alteração do artigo $101, \S 1^{\circ}$ e $2^{\circ}$, para a formação de lista tríplice por um colegiado composto por presidentes dos Tribunais Superiores, Tribunal de Contas da União e o Procurador-geral da República, é de patente de inconstitucionalidade.

Isto porque a proposta de redução do acesso à corte constitucional mediante formação de lista tríplice por órgãos não eleitos gera um esvaziamento de uma tradição histórico-constitucional brasileira de nomeação pelo Presidente como agente político representativo e sujeito aos checks and balances e responsabilização político-jurídica por sua escolha.

Todavia, no que se correlaciona com a proposta de inclusão do artigo $101, \S 3^{\circ}$ e $4^{\circ}$, que fixa um mandato para os Ministros do Supremo Tribunal Federal, considera constitucional uma vez que atende aos princípios republicano e democrático, adequando-se ao modelo adotado pelas principais cortes constitucionais mundiais.

A temporariedade dos cargos é um elemento do princípio republicano, assim como a necessidade de alternância na representatividade corresponde a um elemento do princípio democrático. Ademais, há de se considerar que é modelo adotado pelas cortes constitucionais, tendo referências como Itália, Alemanha e França.

\section{REFÊRENCIAS DAS FONTES CITADAS}

BARCELLOS, Ana Paula de. Papéis do Direito Constitucional no Fomento do Controle Social Democrático: Algumas Propostas Sobre o Tema da Informação in RDE ano 3. N. 12. Out/dez 2008.

BARROSO, Luís Roberto. Judicialização, Ativismo Judicial e Legitimidade Democrática. Revista Direito do Estado, Salvador, ano 4, n. 13, p. 73, jan./mar. 2009. 
. A Americanização do Direito Constitucional e seus paradoxos in: Temas de direito constitucional. t. IV. Rio de Janeiro: Renovar, 2009.

O Reconhecimento Jurídico das Relações Homoafetivas no Brasil. Revista do Ministério Público do RJ.

Curso de direito constitucional contemporâneo. 2 ed. Rio de Janeiro: Saraiva, 2009.

BOBBIO, Norberto Bobbio; MATTEUCCI, Nicola; PASQUINO, Gianfranco. Dicionário de Política. Brasília: Editora Universidade de Brasília, 1998.

CAMPILONGO, Celso Fernandes. O Direito na sociedade complexa. São Paulo: Max Limonad, 2000.

CANOTILHO, José Joaquim Gomes. Direito Constitucional. Coimbra: Almedina, 1992. Comentários à Constituição do Brasil. São Paulo: Saraiva/Almedina, 2013.

COELHO, Rosa Júlia Plá. Mecanismos de Proteção dos Direitos Fundamentais. 1 ed. Brasília: Ordem dos Advogados do Brasil, 2005.

DIMOULIS, Dimitri e LUNARDI, Soraya Gasparetto. Ativismo e Autocontenção Judicial no Controle de Constitucionalidade in: FELLET, André Luiz Fernandes; PAULA, Daniel Grotti de. NOVELINO, Marcelo. As Novas Faces do Ativismo Judicial. São Paulo: Jus Podvim, 2011.

GALLACCI, Fernando Bernardi. O STF e as Cláusulas Pétreas: O ônus argumentativo em prol da governabilidade? São Paulo: SBDP, 2011.

HARBELE, Peter. El Tribunal Constitucional Federal como modelo de uma jurisdicción constitucional autônoma in: HARBELE, Peter. Estudios sobre la jurisdicional constitucional. México: Porrúa, 2005.

JUSTINO DE OLIVEIRA, Gustavo Henrique. Participação administrativa. In: OSÓRIO, Fábio Medina; SOUTO, Marcos Juruena Villela. Direito administrativo e estudos em homenagem a Diogo de Figueiredo Moreira Neto. Rio de Janeiro: Lumen Juris, 2006.

LEWANDOWSKI, Enrique Ricardo. Reflexões em torno do princípio republicano. Revista da Faculdade de Direito da Universidade de São Paulo v. 100 p. 197. jan./dez. 2005

MANCUSO, Wagner Pralon. O Lobby da indústria no Congresso Nacional. São Paulo: EDUSP, 2007.

MENDES, Gilmar Ferreira; COELHO, Inocencio Mártires; BRANCO, Paulo Gustavo Gonet. Curso de Direito Constitucional. São Paulo: Saraiva, 2009. 
MOURA, Emerson Affonso da Costa. Do Controle Jurídico ao Controle Social: Parâmetros a Efetividade dos Direitos Sociais. Revista de Direito Constitucional e Internacional - IBDC. Volume 77. dez 2011.

SANCHÍS, Luis Pietro. Neoconstitucionalismo Y Ponderación Judicial in CARBONELL, Miguel. Neoconstitucionalismos.

SARMENTO, Daniel. A proteção judicial dos direitos sociais. In: ; Souza Neto, Cláudio Pereira de (orgs.). Direitos sociais: fundamentos, judicialização e direitos sociais em espécie. Rio de Janeiro: Lumen Juris, 2008.

SOUZA NETO, Cláudio Pereira de. Deliberação pública, constitucionalismo e cooperação democrática. In: SARMENTO, Daniel (org.). Filosofia e teoria constitucional contemporânea. Rio de Janeiro: Lumen Juris, 2009.

VALLE, Vanice Regina Lírio do. Ativismo Jurisdicional e o Supremo Tribunal Federal. São Paulo: Jiruá, 2009.

VIEIRA, José Ribas; CAMARGO, margarida Maria Lacombe e SILVA, Alexandre Garrido. O Supremo Tribunal Federal como arquiteto constitucional: A judicialização da política e o ativismo judicial. In: Anais do I Forum de Grupos de Pesquisa em Direito Constitucional e Teoria dos Direitos, 2009.

VITAL, Moreira. Princípio da Maioria e Princípio da Constitucionalidade: Legitimidade e Limites da Justiça Constitucional in: Legitimidade e Legitimação da Justiça Constitucional. Coimbra: Coimbra Editora, 1995. 